\title{
Confucianism, "cultural tradition" and official discourses in China at the start of the new century
}

Sébastien Billioud

\section{OpenEdition}

12 Journals

Édition électronique

URL : http://journals.openedition.org/chinaperspectives/2033

DOI : 10.4000/chinaperspectives.2033

ISSN : 1996-4617

Éditeur

Centre d'étude français sur la Chine contemporaine

Édition imprimée

Date de publication : 15 septembre 2007

ISSN : 2070-3449

Référence électronique

Sébastien Billioud, "Confucianism, "cultural tradition" and official discourses in China at the start of the new century ", China Perspectives [En ligne], 2007/3 | 2007, mis en ligne le 01 septembre 2010, consulté le 14 novembre 2019. URL : http://journals.openedition.org/chinaperspectives/2033 ; DOI : 10.4000/chinaperspectives.2033 
C

ב Confucianism, "Cultural

Tradition," and Official

Discourse in China at the

Start of the New Century

SÉBASTIEN BILLIOUD

This article explores the reference to traditional culture and Confucianism in official discourses at the start of the new century. It shows the complexity and the ambiguity of the phenomenon and attempts to analyze it within the broader framework of society's evolving relation to culture.

$\mathrm{H}$ armony (hexie 和諧), the rule of virtue (yi de zhi guo 以德治國): for the last few years the consonance suggested by slogans and themes mobilised by China's leadership has led to speculation concerning their relationship to Confucianism or, more generally, to China's classical cultural tradition. What does the emergence of this new rhetoric mean? How does it fit with the Marxist vulgate? Can it be explained in terms of a simple phenomenon of instrumentalisation? What does this increasing reference to traditional culture indicate about the evolution of contemporary China?

The object of this article is to contribute to the comprehension of the phenomenon on the basis of a body of discourse. It is necessary from the start to clarify certain methodological orientations and limits to this study: (a) our interest is in discourse and not actions. (b) This discourse emanates from the central authorities and from semi-official entities. Thus, we will not explore here the important interaction between an emergent popular Confucianism and authorities at the local level. (c) The category of "Confucianism" is complex and entails very different elements. In this article, we will consider it in its largest sense, focusing thus on all possible direct (explicit use of the term ru 儒, reference to Confucian figures) and indirect (use of concepts associated with Confucian writings) references. In addition, since it factors regularly into allusions made in official discourse, we are interested in another general and imprecise category: cultural tradition (wenhua chuantong 文化傳統) or traditional culture (chuantong wenhua 傳統文化). (1) However, we are excluding from the domain of this study the entire aspect of Chinese tradition that authorities link with religious practices. ${ }^{(2)}$ (d) The relationship the authorities have with tradition at present appears to be intimately tied to the complex and changing relationship that both society and intellectuals have with tradition as well. Thus, we will evoke an important context in this analysis without, unfortunately, being able to go into full detail.

The current renewed popular interest in classical culture, quite significant since the beginning of the current decade, constitutes the background matrix of this study. The phenomenon has taken on "religious" (Buddhism, Taoism, qigong 氣功 and, more generally, all self-cultivation practices), ${ }^{(3)}$ educational (for example, the major

1. In avoiding a precise definition, we are using these two categories of Confucianism and cultural tradition in a provisory manner, as, following the Buddhist notion, a convenience (fangbian 方便); in other words, as categories established at a certain moment because of their usefulness (in this case, as a way to better understand the relationship of authorities to aspects of the pre-republican past) while recognising at the same time their eminently problematic character and limitations.

2. Confucianism is not considered to be a religion in mainland China. In Hong Kong how ever, it is one of the official religions.

3. David A. Palmer, Qigong Fever, Body, Science and Utopia in China, New York, Columbia University Press, 2007. 


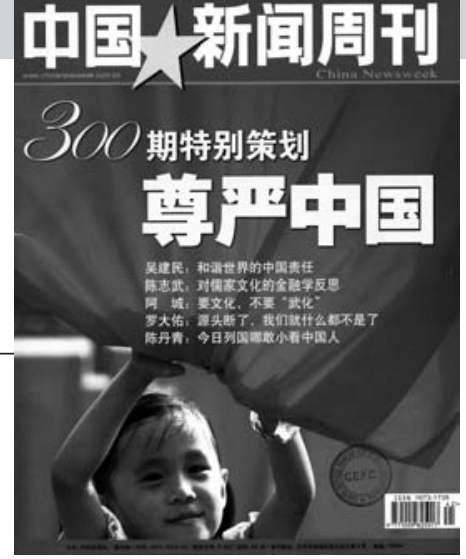

patrimonial, economic and touristic forms. It is also recognisable in terms of mass culture (the craze for historical shows on television, the return of traditional dress, ${ }^{(5)}$ the multiplication of Internet sites devoted to classical culture etc.). In this context, Confucianism, which during the classical era permeated more or less every area of life, is currently being referred to in a fragmented way. ${ }^{(6)}$ In addition, this widespread interest in classical culture has been accompanied by a self-conscious discourse. There has been a profusion of articles and special issues of major national magazines focusing on identity, traditional culture and history, and religious and Confucian revival. ${ }^{(7)}$

At the popular level, China is currently undergoing an exceptional moment of rediscovery and reinvention of a traditional culture that was repressed for a long time.

This rediscovery fits into the larger framework of the extremely rapid evolution of mentalities within a society that has only recently-a point often forgotten-emerged from totalitarianism. It is also powerful evidence of the progressive enlargement of experience and cultural references at both personal and collective levels over the last 30 years. Here we are evoking a movement that extends beyond classical culture: fascination with the West (which was particularly strong during the 1980s), the current rapid growth of Christianity as well as a transformation of certain modes of sociability via Internet are other illustrations of this tendency. This expansion is intimately related to fundamental social change, particularly crises like the increasing sense of insecurity caused by the dislocation of previous structures of cohesion (danwei 單位 or family), the rise of competition (i.e. for education, access to employment) or the pauperisation of specific segments of the population throughout the country. It also reflects the emergence of new aspirations that are far from being only material, despite what is often said.

In post-revolutionary China, the government must come to terms with a context that it both creates and adjusts to. Yves Chevrier has used the phrase "distended communism" (communisme distendu) to describe how the government "allows social groups that it controls only indirectly a margin of liberty without granting them full recognition or complete autonomy." ${ }^{(8)}$ This combination of relative social autonomy and government control appears to determine the reaction of the authorities towards the renewed interest in traditional culture. In loosening its grip, the government itself has created the nec-

essary preconditions for the phenomenon. At the same time, as will be made clear below, it appropriates cautiously certain elements that mesh well with its own objectives and reinforces its legitimacy.

After a quick summary of the relationship between the Communist Party and Confucianism since China's opening, we will examine the extent to which recent official discourse (the five-year plan, speeches by Hu Jintao and Wen Jiabao) refers to traditional culture and Confucianism and which themes are privileged. We will complete this investigation with a little analysis of the discourse emanating from "semiofficial" sources (websites closely linked to the government, ideological publications, etc.). Assessing the importance of Confucianism in current intellectual debates will further enhance the overall perspective of our observa-
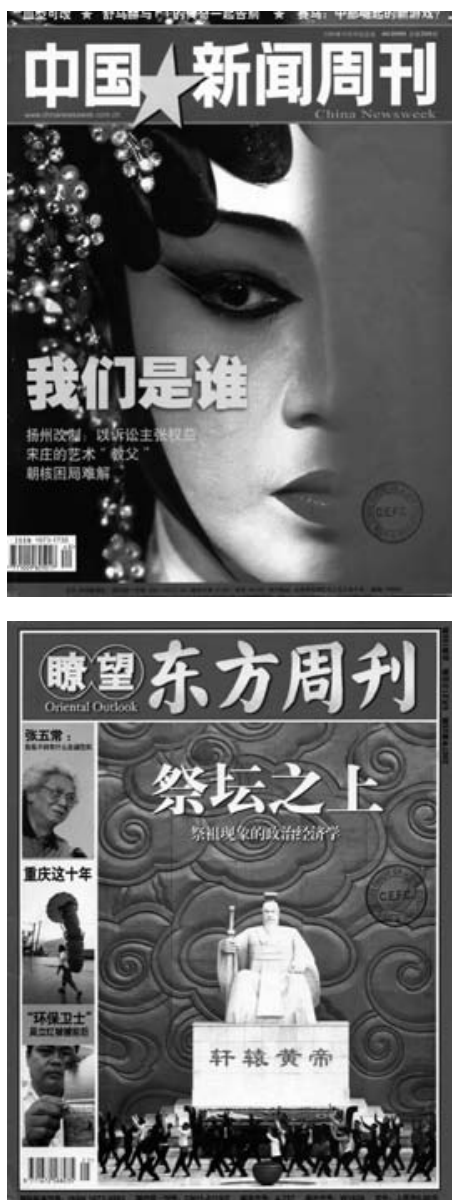

4. An article dealing with this question will appear in the 2007/4 issue of China Perspectives. See as well Ji Zhe, "Traditional Education in China: Conservative and/or Liberal?," Chinese Cross Currents, n. 2.3, 2005, p. 32-41.

5. The most spectacular example of this phenomenon is the "Han Dress Movement" (Hanfu yundong 漢服運動) that has inspired tens of thousands of young people to march through China's large cities dressed in traditional clothing. In another register (the qipao), see as well Matthew Chew, "On the Contemporary Re-emergence of the qipao," The China Quarterly, $n^{0} .189$, March 2007.

6. We introduce this situation in Le Point (special issue : Les textes fondateurs de la pensée chinoise), March-April 2007, pp. 30-33.

7. A few recent examples suffice to illustrate the extent of the phenomenon: The Liaowang Dongfang Zhoukan, one of the leading national weeklies, mentions guoxue re 國學熱 (the fever for national studies) as one of key phrases of 2006, Liaowang Dongfang Zhoukan (Oriental Outlook Weekly), 4 January 2007, pp. 64-65. In another issue, the same magazine dedicates a special feature to the official sacrifices to the great ancestors of Chinese civilisation (issue dated 21/06/2007, pp.10-23). Zhongguo xinwen zhoukan (China Newsweek, $\mathrm{n}^{\circ} .42 / 2006$ ) dedicates a special feature to The Dignity of China (Zunyan Zhongguo) emphasising the role of Confucianism. The issue 40/2006 of the same weekly made its headlines with the question Who are we? (women shi shei 我們是誰) in a special dossier featuring articles on the issues of rites, Han dress, traditional education, Chinese medicine, etc. Another national magazine, Xin Zhoukan (New weekly, nº. 238, dated 01/11/2006) proposed to its readers several articles on the utilisation of history that analyzed, among other topics, the craze for historical TV shows on television. 


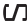

tions. We will conclude by raising a few questions about the nature of contemporary China's relationship to time.

\section{The Party and Confucianism Since China's Opening: A Few References}

"Confucius, thinker and ardent defender of slavery," "Confucius, the great master of the partisans of counter-revolutionary restoration"- the titles of brochures edited against Lin Biao and Confucius during the Culture Revolution give a sense of the distance travelled in the last thirty years. The end of Maoism and the beginning of the policies of liberalisation inaugurated a long process of re-evaluating Confucianism. The question has clearly been a touchy one given the Chinese Communist Party's history of anti-traditionalism as well as the role of Confucianism in republican China and in Taiwan. ${ }^{(9)}$ From the very beginning of the 1980s, traditional Chinese philosophy was featured again as the subject of conferences and articles, at the same time that official organs were created, like the China Confucius Foundation in 1984. ${ }^{(10)}$ At the end of 1986, in the context of the seventh five-year plan, the government authorised the formation of a large research group on contemporary Confucianism directed by Fang Keli, a professor at Nankai University in Tianjin. The contemporary Confucian movement has brought together top intellectuals, including several who fled to Hong Kong, Taiwan, and the United States when the communists came to power. These Confucian intellectuals have achieved prominence through their writings and, in certain cases, through their international activities (i.e. at the Parliament of the World's Religions or at UNESCO). Umberto Bresciani has highlighted two principal motivations for the government to support such a research project: the desire to comprehend better a philosophy that could easily be used as an anti-Marxist tool ${ }^{(11)}$ and the desire to integrate Confucianism, a source of positive economic values, into the narrative of China's long march towards socialist modernisation. The 1980s was a time that saw the eruption of a very Weberian debate over "Asian values" and the development of the four "Asian Tigers." The Party's renewed interest in Confucianism can be better understood once framed by the overall context of the 1980s and the policies of liberalisation. Economic liberalisation and the imperative of modernising the country need to be considered first. Historically, since the end of the dynastic era, both liberals and revolutionary communists have blamed Confucianism and its "feudalism" for China's backwardness and inability to modernise. How- ever, by the 1980s, the situation had obviously changed. Lao Siguang noted at the time that traditional Confucian culture no longer had any force (wuli 無力), ${ }^{(12)}$ thus no harmful influence. A controlled and critical re-evaluation ${ }^{(13)}$ was possible given that, on the one hand, the contemporary Confucian intellectuals were the children of the May $4^{\text {th }}$ movement, ${ }^{(14)}$ and, on the other hand, values attributed to the tradition had paradoxically been cited abroad as having a key role in the process of economic modernisation.

Another key form of liberalisation was cultural, what became known as the "cultural fever" (wenhua re 文化熱). This popular enthusiasm for all things cultural was marked by two dominant tendencies: a prevailing aspiration towards Western modernity, symbolised by the television series, River Elegy (He Shang 河觞); and the rediscovery of traditional culture, especially within the most educated and urbane fringe of society. ${ }^{(15)}$ While this ambiguous interest in traditional culture was not orchestrated by the political authorities, it was tolerated nevertheless and was accompanied with a noticeable shift in tone towards Confucianism. In 1987, Gu Mu 穀牧, the vice prime minister who was also

8. “(un pouvoir) laissant agir des corps sociaux qu'il ne contrôle plus qu'indirectement sans toutefois leur accorder une pleine reconnaissance ni une entière autonomie." Yves Chevrier, "De la révolution à l'Etat par le communisme," Le Débat, no.117 (NovemberDecember 2001) pp. 109-110.

9. See Jennifer Oldstone-Moore, The New Life Movement of Nationalist China Confucianism, State Authority and Moral Formation, doctoral thesis, University of Chicago, 2000; Frederic Wakeman, Jr., "A Revisionist View of the Nanjing Decade Confucian Fascism," The China Quarterly, n. 150, June 1997, pp. 394-432. Zheng Yuan, "The Status of Confucianism in Modern Chinese Education, 1901-1949," in G. Peterson, R. Haynoe and Yongling Lu (ed.), Education, culture and Identity in Twentieth-Century China, Hong Kong, Hong Kong University Press, 2001, pp. 193-216.

10. Concerning this reactivation of Confucianism in the 1990s, particularly in academic circles, see Umberto Bresciani, Reinventing Confucianism, The New Confucian Movement, Taipei, Taipei Ricci Institute, 2001, p. 419ff.

11. His argument is based on Fang Keli's analysis. The argument strikes us as only moderately convincing since it is hard to see why this research project resulted in so many publications.

12. Lao Siguang, "Shilun dangdai fan rujia sichao," in Tu Weiming (ed.), Rujia fashan de hongguan toushi, Taipei, Zhengzhong shuju, 1988, p. 7.

13. Using a Marxist perspective and methodology.

14. As a group, these intellectuals refer to Confucian thought while maintaining an extremely critical perspective on the history of certain practices, particularly imperial ones. Major thinkers like Xu Fuguan, Mou Zongsan, Tang Junyi are democrats (democracy and science for them are universal). Contrary to what certain intellectuals are doing more and more today, they do not advocate a political system directly inspired by Confucianism. From their perspective, Chinese tradition could only contribute to the improvement and correction of a previously established Western-style democracy. During the 1980s it was above all the moral and metaphysical writings of these thinkers that were studied rather than their political texts. In the case of Mou Zongsan, it was not until 2007 that his landmark political work, Zheng dao yu zhi dao, was published on the mainland

15. See Joël Thoraval, "La 'fièvre culturelle chinoise': de la stratégie à la théorie," in Critique, August-September, 1989, pp. 558-572; Joël Thoraval, "La tradition rêvée, réflexions sur l'Elégie du fleuve de Su Xiaokang”, L'infini, 1990, pp.146-68. 
instrumental to the creation of special economic zones, participated in a symposium on Confucianism in Qufu, the first of its kind since the founding of the People's Republic, where he spoke of Confucianism as "a crystallisation of Chinese national culture." ${ }^{(16)}$

Shortly after the events of Tiananmen, Gu Mu participated in another symposium celebrating the birth of Confucius and emphasised his positive role in Chinese history ${ }^{(17)}$ whereas Jiang Zemin also met some of the symposium's speakers. Based on various speeches, Werner Meissner has asserted that "the political leadership clearly functionalised traditional concepts to broaden its dwindling legitimisation after June $4^{\text {th }}$. "He points to the rehabilitation of Zhu Xi, the great Song dynasty thinker the following year. According to Meissner, Confucianism served a dual function for authorities in the 1990s: its "authoritarian" aspects helped contribute to a "socialist spiritual civilisation" and to social cohesion while it also offered a cultural antidote to the threat of westernisation. ${ }^{(18)}$ As early as 1995, Jean Philippe Béja went so far as to evoke the establishment of "national-Confucianism." ${ }^{(19)}$ What is certain is that during the 1990s the government's attitude towards culture in general and Confucianism in particular evolved. The "fever" for national studies (guoxue) at the time, while not reducible to a political strategy, did not occur without the encouragement of the government. ${ }^{(20)}$ Throughout the period, certain high officials made positive passing remarks concerning Confucianism, although mostly in relatively informal circumstances. ${ }^{(21)}$ All this nevertheless needs to be situated within the larger general context: while direct references to Confucianism or to traditional culture were more frequent and more visible than during the preceding decade, they were, nevertheless, very limited. At the beginning of the current decade things appeared to take a new turn.

\section{Confucianism and Traditional Culture in Today's Official Discourse}

\section{A general overview}

The basis of our investigation is body of official texts emanating from the highest levels of state: speeches by $\mathrm{Hu}$ Jintao or Wen Jiabao, the 2001 Action Plan for the Development of Civic Morality (gongmin daode jianshe shishi gangyao 公民道德建設實施綱要, hereafter referred to as the PCM) and especially the 2006 Plan for Cultural Development that figured into the eleventh five-year plan
(2006-2010) (guojia "shiyiwu" shiqi wenhua fazhan guihua gangyao 國家“十一五” 時期文化發展規劃綱要, hereafter referred to as the PCD). Two issues should be explored together: on the one hand, the extent to which these texts make direct reference to traditional culture and Confucianism and on the other hand, beyond any direct references, the overall nature of the discourse along with the new concepts it generates.

The partisans of a Confucian revival ${ }^{(22)}$ (rujia fuxing 儒家復興) hailed the eleventh PCD as great step forward. While socialist references remained predominant in the text, references to traditional culture were prominent from the very first lines:

Chinese culture, with over five thousand years of brilliance, has contributed immensely to the progress of human civilisation. It is the spiritual bond of our national heritage, of our unceasing $d y$ namism, the source of our power of resistance in the face of difficult challenges and a complex world (...).

16. See Song Xianlin, "Reconstructing the Confucian Ideal in 1980s China: the 'Culture Craze' and New Confucianism," in John Makeham (ed.), New Confucianism, New York, Palgrave Macmillan, 2003, pp. 86-87.

17. Idem, p. 87

18. Werner Meissner, "China's Search for Cultural and National Identity from the Nineteenth Century to the Present," China Perspectives, nº. 68, November-December 2006, p. 48.

19. Jean Philippe Béja, "Naissance d'un national Confucianisme?," Perspectives chinoises, $n^{\circ}$. 2, November-December 1995, pp. 6-11.

20. Chen Yan, explores this question in L'Eveil de la Chine, Les bouleversements intellectuals après Mao (1976-2002), Paris, Editions de l'Aube, 2002. He cites (p. 304, note 286) articles in the Renmin ribao from 1993 and 1995 attesting to the government's support of the resurrection of national studies. He also explains (p. 198) that other parameters (academic strategising or, in some cases, genuine conviction) have also contributed to the craze for guoxue.

21. This is notably the case with Li Ruihuan, who was the president of the Chinese People's Political Consultative Congress and a long-time member of the Politburo of the Central Committee before retiring during the Sixteenth Party Congress. At the end of 2005, he published a two-volume collection of his major speeches since the 1980s. Li Ruihuan, Xue zhewue, yong zhexue (Studying Philosophy, Using Philosophy), Beijing, Zhongguo renmin daxue chubanshe, 2006, two volumes. In one speech of 1999 he stated: "More than 2000 years of history have proven that the teachings of Confucianism can inspire us as means to resolve the problems confronting human societies. We must adopt towards these teachings a scientific method and attitude-we must study them, systematise them, synthesise them, keep what is best and reject the rest (...)" (vol. 2, p. 681). This was a speech specifically tailored to an assembly of specialists. More interesting is the fact that this speech was included in a widely disseminated anthology published in 2005 . Willy Wo-Lap Lam has pointed out that Li Ruihuan, Gu Mu and the former governor of Guangdong, Ye Xuanping have all called for a re-evaluation of Confucianism. See Willy Wo-Lap Lam, Chinese Politics in the Hu Jintao Era, New Leaders, New Challenges, New York, Sharpe, 2007, p. 280.

22. We refer here to Confucian activists that we met during our field work on Confucian revival in China today. Some of these activists are intellectuals but many are not and work in a variety of different sectors. 
The need to promote "the eminent national culture" (youxiu minzu wenhua chuantong 優秀民族文化傳統) is reaffirmed in several passages and constitutes one of the directing principles of the plan. ${ }^{(23)}$ The concrete measures representing the implementation of this principle are enumerated in detail. Before reviewing them, it is worthwhile to note the essentially positive role that traditional culture has taken on in the public discourse of the top leadership.

In a speech delivered in February 2007 concerning the initial phase of socialism, ${ }^{(24)}$ Wen Jiabao praised traditional culture and the excellence of some of its aspects: the philosophy of "harmony despite different points of view" (he er bu tong 和而不同, a Confucian concept which has subsequently become a common reference in that it opposes uniformity of thought), of "the people as the basis of the state" (min wei bang ben 民鴬邦本) ${ }^{(25)}$ or of "respecting teachers and valorising studies." (26) In another Wen Jiaobao speech delivered at Harvard in March 2007 and often cited by advocates of Confucianism in China today, the references are even more explicit:

\section{From Confucius to Sun Yat-sen, ${ }^{(27)}$ the traditional cul- ture of the Chinese nation consisted of large number of precious elements, of many positive things concern- ing the nature of a people and of democracy (ren- minxing he minzhuxing 人民性和民族性). It em- phasised, for example, love and the sense of human- ity (ren'ai 仁愛), community (qunti 群體), harmony despite different points of view, what is under heaven is for all (tianxia wei gong 天下爲公)... ${ }^{(28)}$}

Within an ensemble of still overwhelmingly socialist references, there is an essentially positive interpretation of traditional Chinese culture (without too precise a definition of what is meant by "traditional Chinese culture"), maybe more so than what was previously typical.

Adding to the phenomenon in question is an increase in the use of slogans with a decidedly Confucian accent, like "harmonious socialist society" (shehuizhuyi hexie shehui 社會主義和諧社會). How have authorities integrated this new slogan into the standard body of ideological catchwords? A speech by $\mathrm{Hu}$ Jintao in 2005 provides a certain amount of insight since it attempts to provide the slogan with some historical grounding. ${ }^{(29)}$ In the speech the idea of harmony in classical thought is evoked in a paragraph in which Confucius, Mozi, Mencius, the Book of Rites, the leader of the Taiping Rebellion Hong Xiuquan and Kang Youwei are all jumbled together. The concretisation of the ideas of these figures, $\mathrm{Hu}$ goes on to explain, was not possible in a feudal system of class oppression. Without ascribing too much importance to this point, it is nevertheless noteworthy how he makes the distinction between the potential resources that classical thought offers today and the former political system that must still be vigorously condemned. Hu then situates the notion of harmony within the history of socialism in order to establish its genealogy while at the same time acknowledging the opposing notions of contradiction and class struggle. The harmony extolled by utopian socialists (kongxiang shehuizhuyi 空想社會主義) like Charles Fourier and Robert Owen in the nineteenth century did not, according to $\mathrm{Hu}$, sufficiently take into consideration the contradictions at work in capitalism, which was precisely the remedy provided by the scientific socialism of Marx, Engels and Lenin. As for China, Hu carefully

23. However, the promotion of traditional culture is very often accompanied with reminders that China must also absorb the excellent aspects of other cultures. There is a clear desire to find the right balance to avoid unleashing cultural nationalism. The idea of promoting traditional culture already appears in some of the documents contained in previous plans, but the importance accorded this notion is, at least on paper, much more pronounced in the eleventh plan which for the first time contains such a large section devoted to culture.

24. This notion was officially adopted by Zhao Ziyang in his report to the National Party Congress in October 1987 and was taken up again by Jiang Zemin in 1997. For Zhao Suisheng, "the primary stage concept conveyed an old mixture of pride and humility: It simultaneously celebrated the historical achievement of China's socialist revolution and recognised the flaws in China's economy and its underdevelopment." Today it is the imbalances of development that are often referred to. Suisheng Zhao, A Nation-State by Construction, Palo Alto, Stanford University Press, 2004, p. 225

25. The aphorism Min wei bang ben 民鴬邦本 first appears in the Book of Documents (Shangshu 尚書). It also commonly appears in a condensed version as minben 民本. Wang Enbao and Reina F. Titunik have studied its usage (notably by Confucius, Mencius, Huang Zongxi) and indexed various studies from the past devoted to the concept, including one by Liang Qichao. They have also made the connection between the notion of minben and Sun Yatsen's Three Principles of the People (as well as Sun's notion that "what is under heaven is for all," tian xia wei gong, which is also used in contemporary political discourse. Cf. infra). They explain that concept of minben has become fashionable within circles close to the top leadership since the 1990s. Enbao Wang and Regina F. Titunik, "Democracy in China, The Theory and Practice of Minben," in Suisheng Zhao (ed.), China and Democracy, New York, Routledge, 2000, pp. 73-83. This essay is another in a longstanding line of works that attempt to find within Chinese tradition concepts that are susceptible to facilitating the combination of that tradition with Western-style democracy.

26. Wen Jiabao, "Guanyu shehuizhuyi chuji jieduan de lishi renwu he wo guo dui wai zhengce de ji ge wenti (Concerning a Few Questions Relative to the Historic Duty of the Initial Phase of Socialism and Our Country's Foreign Policy);" http://news. xinhuanet.com/lianzheng/2007-02/26/content 5775737.htm consulted on 6 April 2007

27. The comparison of Confucius with Sun Yat-sen is linked indirectly to a quotation from a text by Mao from 1938, "Zhongguo gongchandang zai minzuzhanzheng zhong diwei (The Role of the Chinese Communist Party in the National War)" ; see Wang Xingguo, Chengnian Mao Zedong yu ruxue (Mao as an adult and Confucianism) http://www.mzdlib.com/xsyj/display.asp?Reco_ID=2992, consulted on 9 June 2007.

28. Wen Jiabao, "Ba mugang toushexiang Zhongguo (A Look at China)," http://news. phoenixtv.com/special/wenzong/waijiaofengcai/200703/0301 $76481517 . s h t m l$, consulted on 5 April 2007. In the same speech, Wen Jiabao mentions a visit with the philosopher Ji Xianlin. Ji Xianlin, who is a "consultant on artistic matters" (yishu guwen 藝術顧問) for the 2008 Olympic Games in Beijing, has proposed including a special reference to Confucius during the opening ceremonies. http://news.cctv.com/sports/ aoyun/other/20070830/101574.shtml , consulted on 30 August 2007.

29. Speech of 19 February 2005: "Hu Jintao guanyu goujian shehuizhuyi hexie shehu jianghua quanwen (The Complete Text of Hu Jintao's Speech on the Establishment of a Harmonious Socialist Society)," http://www.china.com.cn/chinese/news/899546.htm. 
demonstrates the contribution of each generation of leaders to the idea of harmony, even if the Maoist record on this score was rather mixed. The primacy of contradiction for the Great Helmsman is hinted at through a commentary on the second generation of leadership (that of Deng Xiaoping), which "abandoned the erroneous line that consisted of attributing a central role to class struggle" (yi jieji douzheng wei gang de cuowu fangzhen 以階級鬥争爲綱的錯誤方針). Advocating a harmonious society today, the text makes clear, is not a matter of denying the existence of contradictions within society, but one of "resolving them in the appropriate fashion" (tuoshan chuli 妥善處理).

Various studies have highlighted the historical ambivalence of the Chinese Communist Party (CCP) towards the concept of contradiction and of class struggle. Arif Dirlik has pointed out the existence of a profound ambiguity at the hear of Chinese socialism throughout the twentieth century characterised by a tug of war between promoting the interests of the working class and avoiding class conflict. ${ }^{(30)}$ Kalpana Misra-who refers to Dirlik's work, but also to that of Li Yuming and of Levenson, has demonstrated how the hard line Maoism of the 1960s and 1970s clashed with a preference for harmony among elites, a conflict which revealed itself, at various times and contexts in different guises, like the united front, the "collaboration of the four classes" or "the democratic dictatorship of the people." (31) Hu Jintao's speech, despite its careful effort to recall various episodes in the evolution of Marxist theory, ${ }^{(32)}$ overwhelmingly gives the impression that the idea of contradiction, once stripped of all philosophical underpinning (as a law of development or a principle of epistemology), ${ }^{(33)}$ boils down to simply describing concrete problems that can be resolved through the appropriate policy. It is true that the mystique of contradiction (and its most obvious avatar, class struggle) has left centre stage for some time. Nevertheless, its absorption/dissolution into the concept of harmony-a concept with which it has always been in opposition-might indicate a significant turning point in official discourse. It is a pragmatic shift that opens the door-at least in theory-to reconciling the interests of the emerging bourgeoisie with a commitment to fighting against social cleavages. It is also a clever theoretical innovation that preserves a certain ideological continuity while at the same time evoking "tradition" in a highly vague manner.

Assuring the unity of the people is one of the principle functions of culture as outlined in the eleventh PCD. ${ }^{(34)}$ Culture must provide the "spiritual resources" for constructing a har- monious socialist society and achieving a "moderately prosperous society" (xiaokang shehui 小康社會). ${ }^{(35)}$ From this standpoint, traditional culture is particularly vital in three domains: morality, education, and social cohesion.

\section{The question of morality}

The second section of the eleventh PCD takes up the question of morality under the heading "Reinforcing socialist morality." ${ }^{(36)}$ Like the billboards put up in the last few years by neighbourhood committees across the country, the text emphasises from the outset the necessity of both the rule of law (yi fa zhi guo 以法治國) and the rule of virtue (yi de zhi guo 以德治國). The general tone of the text reflects an attempt to find the proper balance between or synthesis of references to socialism and references to the national spirit (or to traditional culture), while at the same time insisting on the importance of being in synch with the Zeitgeist (shidai jingshen 時代精神), as if to defuse any temptation towards exclusive reference to tradition). Three key elements are highlighted. First, there is the necessity to work towards raising the "moral level of the people" (gongmin de daode suzhi 公民的道德素質). Here we find the continuation of the arguments of the

30. Arif Dirlik, The Origins of Chinese Communism, Oxford, Oxford University Press, 1989, p. 64. In some ways, the spectre of harmony has always haunted Chinese socialism, even during those periods in which contradiction and class struggle were at the forefront of ideological theorising.

31. Kaplana Misra, From Post-Maoism to Post-Marxism, the Erosion of Official Ideology in Deng's China, New York, Routledge, 1998, pp. 148-150.

32. In one passage, Hu makes an explicit allusion to contradiction as the fundamental motor of social development.

33. By epistemology, we mean the way in which contradiction has been able to be though of as an instrument for the discovery of the truth. On the philosophical foundations of the idea of contradiction, see Frederic Wakeman Jr., History and Will, Philosophical Perspectives of Mao Tse-Tung's Thought, Berkeley, University of California Press, 1973, pp. 295-301.

34. PCD, introduction.

35. The notion itself is of Confucian inspiration. It is found in the part of the Book of Rites (Liji 禮記) concerned with “the evolution rites” (Liyun 禮運) in which three ages are distinguished: the age of Great Unity, Datong 大同, which refers to the idealised golden age of those paragons of virtue, Yao and Shun; that of relative peace (which is how in this context xiaokang 小康 can be translated), an intermediate stage of the enlightened rule of the sovereigns of late antiquity; and finally the troubled age of Confucius when the Sage asserts that the Way has been forgotten. Dividing history into ages will become a recurring practice, one most notably taken up during the Han dynasty by He Xiu 何休 (129-182) and at the end of the nineteenth century by Kang Youwei 康有鴬 (1858-1927), who reverses the historical logic: the age of xiaokang is embodied by the West at the time of Kang's writing whereas the Great Unity becomes a utopian dream of the future, developed in his Datong Shu 大同書, of a united humanity.

36. In part 6 , Jiaqiang shehuizhuyi sixiang daode jianshe: literally, it is a question of the "morality of socialist thought." 
PCM $^{(37)}$ written five years earlier. Next, the (socialist) conception of "honours and shames" (rongruguan 榮辱觀), popularised by the slogan "eight honours and eight disgraces" (ba rong ba chi 八榮八恥). ${ }^{(38)}$ Many promoters of a Confucian revival consider this recourse to shame in the slogan as a direct reference to traditional moral philosophy. ${ }^{(39)}$ The eleventh PCD calls for the integration of the ba rong ba chi into school textbooks, where, in fact, the amount of space and the pedagogical role assigned to traditional culture has evolved in the last few years. The last of the three elements emphasised is the moral and patriotic indoctrination of youth.

This moral indoctrination campaign seeks to get to the root of a set of clearly identified problems. ${ }^{(40)}$ While peppered with Confucian elements, it fits into a certain historical continuity. Before 1949, despite the anti-traditionalist bent of the May $4^{\text {th }}$ movement, the governments in place actively contributed to the promotion of Confucian-inspired moral education. Emblematic of this kind of educational policy was the use of Dai Jitao's 戴季陶 theories linking Confucianism and Sun Yat-sen's Three Principles of the People by the government of Chiang Kai-shek. ${ }^{(41)}$ Once the communists came to power, the discourse changed radically but certain structures of thought persisted. Numerous studies have drawn attention to this continuity. ${ }^{(42)}$ In a work on Marxism in China, Li Zehou 李澤厚 demonstrates the extent to which Chinese communism, far from limiting itself to the system of socialist ethics that is discernible in some Western currents of Marxism, is impregnated with the tradition of self-cultivation (xiuyang 修養) and "inner Sainthood" (neisheng 内聖) under the guise of "a moralism aiming at reforming individual thought." " ${ }^{43)}$ Jin Guantao has used the phrase "the Confucianisation of Marxism" to describe this phenomenon, which he claims began during the republican era. ${ }^{(44)} \mathrm{He}$ points to an essay written by Liu Shaoqi first published in 1940 as a good illustration of the evolution in question." "(45) "On the Self-Cultivation of Chinese Communist Party Members" (Lun Gongchandangyuan de xiuyang). ${ }^{(46)}$ The Marxist project of social transformation is linked to the necessity of personal transformation (gaizao ziji 改造自己) with Marx and Lenin serving as examples. Having incorporated a certain élan associated with the question of self-cultivation, Marxism evolves and by the 1950s, according to Jin Guantao, becomes for the Chinese a form of moral idealism. Li Zehou, in the work cited above, compares the Communist Party under Mao with the Confucian tradition, identifying in both cases a "trinity" (san he yi 三合一) involving religion (zongjiao 宗教) ethics (lunli
37. Gongmin daode jianshe shishi gangyao (Draft Plan for the Building Up of Public Morality), see http://news.sina.com.cn/c/2001-10-24/385297.html, consulted on 6 April 2007. There is a long historical precedent for discourse on public morality. This is a poin made by Pierre-Etienne Will in the introduction to La Chine et la démocratie. In line with Philip Kuhn's arguments, Will emphasises how this conservative approach, rooted in the classical era, continues "to dominate modern Chinese history, including the most recent history" and generate a discourse that is opposed to democracy. Pierre-Etienne Will "L'histoire n'a pas de fin," in Mireille Delmas-Marty and Pierre-Etienne Will (ed.) La Chine et la démocratie, Paris, Fayard, 2007, pp. 14-15.

38. This "notion of eight honours and eight disgraces" was the subject of a speech by Hu Jintao in March 2006. See: http://news.tom.com/2006-03-08/000N/39000992.html, consulted on 6 April 2007. The slogan is often transformed into an object of ridicule on the part of the general public (I thank Daniel A. Bell for having drawn my attention to this point).

39. Concerning the question of Confucianism and shame, see the article by Bryan Van Norden, "The Virtue of Righteousness in Mencius," in Kwong-loi Shun, David B. Wong (ed.), Confucian Ethics: A Comparative Study of Self, Autonomy, and Community, Cambridge, Cambridge University Press, 2004. In exploring the very "Mencian" virtue of righteousness, which is likely to make itself known in ordinary life as the feeling of shame, Bryan Van Norden shows that the question of shame was a more important factor to life in ancient China than in ancient Greece and that this had significant implications later on.

40. It is interesting to observe which terms are used to describe these problems. For example, in the PCM (section 1, subsection 2): the cult of money (baijinzhuyi 拜金主義), the cult of pleasure (xianglezhuyi 享樂主義), unbridled individualism (jiduan gerenzhuy 極端個人主義), the putting of personal interest above all sense of justice (jian li wang $y i$ 見利忘義, with the classic opposition between $/ i$ 利 and $y i$ 義), of private interest above the common good (sun gong fei si 損公肥私, directed at problems of corruption and influence peddling), the inability to distinguish between good and evil (shan 善 and $e$ 惩) or truth and falsehood (shi 是 and fei 非 — understood as targeting falungong). Finally, as a kind of echo to the theme of a crisis of confidence (chengxin weiji 誠信危機), there is the question of confidence (in terms of relations between individuals, xinyong 信用). Patriotic and moral indoctrination campaigns responding to different situations are a constant of the Chinese regime. For example, after the Tiananmen Square movement, a major patriotic indoctrination campaign (reasserting control over students and workers), guoqing jiaoyu 國情教育, was launched resulting in a directive in 1994. Guoqing 國情 corresponds to the situation of the country or its "intrinsic circumstances." For more on this concept of guoqing, see G. Barmé, In the Red, New York, Columbia University Press, New York, pp. 257, 446-447, notes 15-18. The ancient term guoqing (which appears in the Warring States Records, Zhanguo ce) has had a rich and complex history since the nineteenth century. Barmé focuses on all the literature on the subject since the 1980s. The term still frequently appears in speeches today.

41. Zheng Yuan, "The Status of Confucianism in Modern Chinese Education, 1901-1949," op. cit., pp. 193-216. The new regulations put in place in 1912 significantly weakened the place of Confucian moral education in school curricula. However, by 1915, with Yuan Shikai, and even more so with Chiang Kai-Shek, Confucianism-inspired moral education came back in force.

42. On this point see Kalpana Misra, "From Post-Maoism to Post-Marxism," op. cit., p. 204

43. Li Zehou, Makesizhuyi zai Zhongguo (Marxism in China), Hong Kong, Mingbao chubanshe, 2006, p. 44. This text is a reprint of a 1987 text (Shi tan Makesizhuyi zai Zhongguo, An Attempt to discuss Marxism in China) supplemented with a long interview from 2006 (Zai tan Makesizhuyi zai Zhongguo, A Second Discussion of Marxism in China) and five annexes, including one that is a long interview with Frederic Jameson, who is extremely influential in China (particularly among thinker known as the "new left). Terms like daode xiuyang continue to be widely used today. For an example, see PCM (section two, subsection 10).

44. Jin Guantao, "Dangdai Zhongguo Makesizhuyi de rujiahua," (The Confucianisation of Marxism in Contemporary China), in Tu Wei-ming (ed.), Rujia fazhan de hongguan toushi, Taipei, Zhengzhong shuju, 1988, pp. 152-183. According to Jin, the sinicisation (which in this context means Confucianisation) of Marxism began in the 1930s, when a number of important intellectuals joined the Communist Party, motivated primarily by the desire to fight the Japanese and save the country. They did not share the same outlook as the first Marxists who were attracted by historical and dialectical materialisms (pp. 156-157). While a distinction between the two groups remains valid, the set of reasons that China's first Marxists were attracted to Marxism is probably more complex than what is argued by Jin. For example, Artif Dirlik has pointed out the important role of anarchism among the intellectuals of the May 4th Movement. Arif Dirlik, The Origins of Chinese Communism, Oxford, Oxford University Press, 1989 
倫理) and the political (zhengzhi 政治). ${ }^{(47)}$ For Li, CCP rule finally embodied a kind of theologico-political (zhengzhi zongjiao 政治宗教) ${ }^{(48)}$ power. Of course, the situation in China today is no longer the same but it is important to keep in mind a certain historical continuity. Mass mobilisation campaigns have mostly disappeared with the onset of liberalisation; what remnants there have been have been on a more limited scale. ${ }^{(49)}$ Individuals have carved out a considerably larger sphere of autonomy. However, the discourse of moral indoctrination continues to play a role of varying importance and, at present, it gives the impression of reclaiming, at least to a certain extent, an ambiguous Confucian inspiration. In a way, the core Marxist vulgate, already significantly sinicised, appears, at least on the surface, to be undergoing a partial and careful process of re-Confucianisation.

The promotion, based on moral indoctrination, of a highly ethical and political conception of education relies to a large extent on articulating some form of philosophical justification. The clear affirmation of the availability of a knowledge (concerning man, society, history, etc.) both legitimates a certain type of indoctrination and establishes its contours. In her analysis of the foundations of the Chinese regime's legitimacy, Vivienne Shue has identified three factors (access to Truth, Benevolence towards the people, Glory) that she traces historically back to the end of the imperial era while emphasising their pertinence throughout the Maoist years and up to the present. ${ }^{\left({ }^{(0)}\right)}$ The "Truth" that particularly concerns us here is no longer a Confucian one: it is, based on the primacy of scientific empiricism, a teleological conception of modernity, one that is a source of positive and transcendent ethical values (progress, etc.). ${ }^{(51)} \mathrm{As}$ far as this study is concerned, the actual details of this Truth matter less than the fact that it has been clearly recognised as available and consequently may constitute a basis for ethical and political indoctrination. ${ }^{(2)}$ To some extent, Shue's analysis matches that of another important recent work, Thomas Metzger's A Cloud Across the Pacific, ${ }^{(33)}$ which focuses not on official discourse but on that of intellectuals. Analysing major works of political theory in contemporary China, the book identifies a constant beyond the different schools of thought distinguished in the text (Marxism, Sunnism, liberalism, Confucian humanism): the existence of a recurrent "epistemological optimism" - in other words, a conviction that a system that can explain reality (history, values, etc.) is available. ${ }^{\left({ }^{4}\right)}$ Metzger goes on to show how this epistemological optimism coincides with the promotion of a form of paideia or a conception of education imbued with a strong
社会主义荣愿观

lhe socialist concept of glory and disgrace

以热爱祖国为荣 以危害祖国为耻

以服务人民为荣 以背离人民为耻

以崇尚科学为荣 以愚昧无知为耻

以辛勒劳动为荣 以好逸恶劳为耻

以团结互助为荣 以损人利已为耻

以诚实守信为荣 以见利忘义为耻

以買纪守法为荣 以违法乱纪为耻 以艰苦奋斗为荣 以骄奢淫逸为耻

Glory in loving the motherland, regard harming the motherland as disgrace.

Glory in serving the people, regard disserving the people as disgrace.

Glory in pursuing science, regard ignorance and unenlightened as disgrace.

Glory in working hard, regard indolence as disgrace.

Glory in teamwork and helping one another,

regard self-seeking as disgrace.

Glory in honesty and faithfulness, regard

mercenariness and profit-grabbing as disgrace.

Glory in being disciplined and law-abiding, regard

violation of laws and disciplines as disgrace.

Glory in living thriftily and strueging, regard sybaritism as disgrace.

ethical and political dimension. ${ }^{(55)}$ Vivienne Shue undertakes a fairly comprehensive analysis of the political and its

45. Ibid., p. 158

46. This text is better known in France under the title "Pour être un bon communiste" (How to be a Good Communist), which does not reflect the traditional idea of xiuyang (selfcultivation) found in the Chinese title.

47. Li Zehou, Makesizhuyi zai Zhongguo, op. cit., p.97

48. Ibid., p. 105

49. The campaign against falungong is a recent example of mass mobilisation (press, work units, schools, neighbourhood committees, etc.) but it has not taken on the massive proportions of Maoist China.

50. Vivienne Shue, "Legitimacy Crisis in China?," in Peter Gries and Stanley Rosen (ed.) State and Society in 21st Century China: Crisis, Contention and Legitimation, New York, Routledge, 2004, pp. 24-49, p. 33, for the idea mentioned here.

51. Ibid., p. 33. It is also in this context that the campaign promoting a Conception of scientific development (kexue fashan guan) can be also situated (even though its implications are both much broader and practical as well). On this point see Heike Holbig "Wissenschaftliches Entwicklungskonzept, Harmonische Gesellschaft und Eigenstaendige Innovation: Neue parteipolitische Prioritaeten unter Hu Jintao,"in China acktuel, $\mathrm{n}^{\circ}$. 6/2005, p. 16. Kexue fazhan guan 科學發展觀 made its appearance in official discourse in 2004. It has been decided to incorporate it into the Party constitution during the Seventeenth Congress of the CCP in October 2007.

52. It is interesting to compare the importance of ethical and political education in China with the situation in the West. Using France as an example, C. Lefort, C. Castoriadis and M. Gauchet have all written of the decline of such a dimension to education. See Sébastien Billioud, "De l'art de dissiper les nuages, réflexions à partir de la théorie politique de Thomas Metzger", Etudes Chinoises, vol. XXVI, 2007 (forthcoming).

53. Thomas Metzger, A Cloud Across the Pacific: Essays on the Clash between Chinese and Western Political Theories Today, Hong Kong, The Chinese University Press, 2005.

54. Metzger's thesis is supported by Kalpana Misra, who points to the existence of a faith in a "capitalist telos," which has replaced the socialist one among the partisans of neoauthoritarianism or neo-conservatism.

55. For a critical analysis of Metzger's work see Sébastien Billioud, De l'art de dissiper les nuages, réflexions à partir de la théorie politique de Thomas Metzger, op. cit. This article focuses on the problems and limits of the notion of "epistemological optimism," with a particular interest in the questions of elitism and paideia.

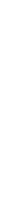

(1)


U

sources of legitimacy. Thomas Metzger dissects contemporary theory. While their studies differ in focus, both authors place epistemology at the centre of their political reflection. Another author whose conclusions somehow echo those mentioned above is Yves Chevrier, who outlines the Party's objective of "situating the legal order within a higher normative order," a (communist) morality historically constituted. ${ }^{(56)}$ Aside from the question of a possible "Confucian or traditional turn" ${ }^{(57)}$ to the current moral education campaign, what is clear is the persist link between the primacy of a state-affirmed vision of the world and the state's continued commitment to fashioning individuals.

\section{The promotion of traditional culture in the schools}

Having examined the question of morality, we can continue our study of official discourse and the eleventh PCD by taking into consideration the document's seventh part, which is devoted to the preservation of national culture. Of particular interest in this part of the text is the campaign to promote traditional culture in the schools whose objective is not outlined in the second section on morality analysed above. ${ }^{(58)}$ Two points draw our attention immediately: first (in section 28), the call for the re-edition of major classical texts. Edition work on Qing history, as well as "the important and great project" of "preserving and protecting national classics," figure in this section of the document. The publication of classic texts of minority groups is also mentioned. Section 30 goes on to stress the importance of education in the domain of "China's remarkable traditional culture" (zhonghua youxiu chuantong wenhua 中華優秀傳統文化) and classical literature. Explicitly stipulated is that:

\section{In those schools where it is possible classes in callig- raphy, painting and other classical arts should be es- tablished. At the middle school level, the proportion of compositions on poetry and the classics must be increased during Chinese classes. In primary schools and middle schools, links between the specificities of the various disciplines instructed and traditional Chi- nese culture need to be emphasised.}

Moreover, the plan calls for the promotion of classical culture at the post-secondary level and in society.

Within the "Confucian revival movement," those interlocutors we have been able to meet during our field study have all stressed the innovative nature of these measures.
It will be interesting during the years to come to observe the changes in school curricula as a measure of the "turn" with regard to classical culture currently taking place. Which classical texts will be privileged? How will they be read (or memorised) and explained? How will teachers be trained? We can provide no answers here. However, we must insist once again on a fundamental contextual element. This interest for traditional literature and culture in all its forms-beyond just Confucianism-can in no case be analysed only in terms of top-down instrumentalisation. It reflects a much larger popular aspiration. After years of gestation, the craze for traditional culture that has become more and more apparent in the last few years goes way beyond any political framework and is rooted as well in popular practice. Examples of this phenomenon at the grassroots level in today's China are manifold: the rapid spread of a movement to encourage children to read classical literature (xiao er $d u$ jing 小兒讀經), ${ }^{(59)}$ an enthusiastic rediscovery of the major canonical texts, ${ }^{(60)}$ an interest on the part of many entrepreneurs in Confucianism, ${ }^{(61)}$ the opening of private schools where studying the classics once again has taken on a special importance (sishu 私塾, xuetang 學堂, shuyuan 書院), a return to traditional styles of dress, a craze for television shows with historical themes, a multiplication of websites on classical culture, etc., not to mention the massive return of religion, especially Buddhism. These few examples testify to the profound changes that

56. Yves Chevrier,"De la révolution à l'Etat par le communisme," op. cit., p.111. Moreover Chevrier emphasises that "the rule of virtue" (yi de zhi guo 以德治國) represents "a borrowing from the past completely devoid of any meaning associated with the past." (Un emprunt au passé dépourvu de toute signification passéiste).

57. As classical literature and Confucian references increasingly become key elements of school curricula, it will be interesting to determine to what extent there is a real evolution in the system of values promoted. At present it is still too early to discern any significant change.

58. During the republican period, courses in which classical literature was studied (dujing 讀經) were already distinct from those devoted to moral perfection (xiushen 修身). Gan Chunsong, Zhiduhua rujia ji qi jieti (Institutionalised Confucianism and its dismantlement)," Beijing, Zhongguo remin daxue chubanshe, 2003, pp. 220-242.

59. This movement might currently involve tens of millions of children. See Ji Zhe "Traditional Education in China: Conservative and/or Liberal?", Chinese Cross Currents, $n^{\circ} .2 .3,2005$, pp. 32-41.

60. Perhaps the most spectacular example of this craze is the great success of a television show about the Analects of Confucius, which features the very charismatic Yu Dan and her lively and topical interpretations of the sayings of the great Sage. A book based on the show has also been a big hit, with almost four million copies sold. Yu Dan has also interpreted texts by Zhuangzi.

61. Two phenomena attest to this fact: on the one hand, a growing number of entrepreneurs are enrolling in special programmes offered by universities throughout the country that feature instruction on aspects of classical culture; on the other hand, the ideal-type of "the Confucian entrepreneur," (rushang 儒商) who simultaneously strives for moral cultivation and to fulfil his responsibility to society (and his employees), has emerged. 
Chinese society is undergoing. ${ }^{(62)}$ It is precisely in this context that the political usage of culture and the policy of promoting traditional culture in the schools have to be situated. Government policy, in this sense, is more a matter of dynamic interaction with an ongoing and widespread cultural phenomenon than a directive from on high. It makes possible an expansion of the range of experience for individuals, a deepening of their relationship to certain aspects of their own history and culture. At the same time, policy adapts and responds to the demand made possible, producing a tradition that serves the interests of the state and reinforces social cohesion.

\section{Mobilising strong symbols of cohesion}

The eleventh PCD explicitly stipulates (part 7, section 29) the need to encourage the potentially positive role of important holidays and customs "with careful attention to the reorganisation of their content and rituals, festivals and popular traditions that embody a strong national character need to be fostered." The plan goes on to cite a large number of major festivals like chunjie 春節, yuanshaojie 元宵節, qingmingjie 清明節, etc. The key condition governing their celebration, which the plan stresses repeatedly, is that they reflect the spirit of the present era. New forms must be found to which celebration can be adapted. On this point, the document does not provide more details. These traditional festivals, celebrated in the past in a diverse fashion depending upon the region, were all intimately linked to popular religion, to a whole body of beliefs deemed to be "superstitions" by the authorities of today. In addition, the festivals were often an occasion to ask for an increase of descendants (qiuzi 求子), something basically incompatible with current family planning policies. In any case, the Party faces the challenge of reappropriating these traditions without losing sight of the fact that it's own history is intrinsically rooted in the fight against "feudalism." We have here a textbook case of what Hobsbawm means when he evokes "the use of ancient materials to construct invented traditions of a novel type for quite novel purposes." ${ }^{(63)}$ It must be emphasised, however, that, in the case of the PCD, the reinvention of tradition is made explicit and is clearly articulated in such terms: above all, it is an effort to reactivate elements of the cultural patrimony considered to be of use for today's purposes.

The PCD also explicitly makes provisions for the "continued amelioration of activities and ceremonies in hon- our of the ancestors of the Chinese nation." In the end, "it is essential to reinforce the cohesion of the Chinese nation and further the creation of a harmonious society." This section also mentions national holidays celebrating labour and the Party, however, interestingly enough, those holidays are discussed as a secondary matter. The document nevertheless reflects a clear concern that elements of traditional culture be integrated with the socialist heritage. The ceremonies associated with the cults devoted to great mythical and tutelary figures like $\mathrm{Yu}$ the Great 大禹 (in Shaoxing, Zhejiang province) or Huangdi 黄帝, the Yellow Emperor (in Huangling, Shaanxi province) have increasingly become the object of extensive media coverage. ${ }^{(64)}$ Moreover, the Ministry of Culture has even decreed these two cults that honour figures featured in the canonical texts associated with Confucianism to be "national cults" (guoji 國祭, as the cult of Yu the Great has been defined since 2007). ${ }^{(65)}$ In his study of the cult devoted to Huangdi, Térence Billeter has highlighted the continuity in the homage paid to The Yellow Emperor throughout the twentieth century (except during the Cultural Revolution) as well as the evolution of the discourse involved in his veneration. ${ }^{(6)}$ Building up on his research on Huangdi, he defends a broader thesis concerning contemporary Chinese nationalism and explains to what extent the utilisation of the past aims at

62. In the 2007/4 issue of China Perspectives we will consider further the rapid growth of a movement aiming to rejuvenate traditional education and the study of the classics.

63. Eric Hobsbawm, Terence Ranger (ed.), The Invention of Tradition, Cambridge, Cambridge University Press, 2003, p. 6

64. See for example a recent issue of a major weekly (Liaowang dongfang zhoukan, owned by Xinhua News Agency) which dedicated a series of articles and a cover to the rites associated with and the ceremonies devoted to the Yellow Emperor, "Jitan zhi shang, jizu xianxiang de zhengzhi jingjixue (On Sacrificial Space, the Political Economy of the Phenomenon of the Major Rites of Ancestor Cults"), in Liaowang dongfang zhoukan, 21 June 2007, pp. 10-23. The articles contain several examples of ceremonies, while paying a special attention to the cult of the Yellow Emperor. Along with their political dimension, the magazine highlights the significant economic and touristic dimensions of the ceremonies.

65. Ceremonies in honour of Yu the Great have been held in Shaoxing, in Zhejiang province since 1995. In 2007 the ceremonies took place on 27 April and were jointly sponsored by the Zhejiang Provincial Ministry of Culture and the Ministry of Culture in Beijing, thus conferring a national character (guojia ji 國家祭) to the celebration. http ://zinews.zjol.com.cn/05zinews/system/2007/04/10/008323624.shtml, consulted on 19 June 2007.

66. Térence Billeter, "Chinese Nationalism Falls Back on Legendary Ancestor," China Perspectives, $n^{\circ}$. 18, July-August 1998, p. 44. See also the doctoral thesis that Billeter wrote on the subject at the Institut d'Etudes Politiques de Paris that has been published as L'Empereur jaune. Une tradition politique chinoise, Paris, Les Indes savantes, 2007. Also see the speech by Li Ruihuan, "Zhengxiu baohu hao Huangdi ling (A Call for the Restoration and Preservation of Huangdi's Tomb)," in Xue zhexue, yong zhexue, op. cit., p. 689 . 
odically cited in other texts but always with the greatest prudence. While everything that we have considered so far suggests that China is currently undergoing some kind of critical reevaluation of its traditional culture, there remains the question of Confucianism as a direct reference and of Confucius himself. In order to understand the difficulty that any direct reference to Confucius entails, we must first remind ourselves that the legitimacy of communism in China has always been rooted in its rejection of all forms of "feudalism." Moreover, what makes the question particularly sensitive is the manner in which the Kuomintang and the regime in Taiwan have made use of Confucianism. Finally, it is necessary again to insist upon focusing our analysis on the most recent context, one that has seen a widespread propagation of "elements" of or references to Confucianism, for it is this development that differs significantly from what was prevalent in the 1990s. ${ }^{(72)}$ While the Party is indeed interested in using all available resources to reinforce its legitimacy, it is not prepared to lose control, nor let its agenda be dictated by what it could perceive as radical forms of cultural conservatism.

Visiting official and semi-official websites (especially online forums and message boards) $)^{(73)}$ makes it possible to "take the temperature" of the situation in 2007 and to examine the kind of discussion currently taking place as well as the semiofficial positions circulating (opinions of Party school professors, high ranking civil servants etc.). These discussions are interesting since they are often more spontaneous and less carefully prepared than the official discourses and texts that we have analysed above. While considering them, however, it is all the more important to be prudent in attempting to link such pronouncements with the official position towards Confucianism. What follows is just an example of the kind of discussion that can be found on official sites in 2007. It is by no means an exhaustive survey of the enormous mass of information available online. The first point to be emphasised is that the question of Confucianism's role is sometimes directly discussed. For example, posted on the site of the Central Party School (CPS) at the beginning of 2007 was a clarification concerning "national studies" (guoxue 國學):

As for those intent on using Confucian doctrine (rujiao 儒教) as a way to replace Marxism, to confucianise China (ruhua Zhongguo 儒化中國) or confucianise the Communist Party, Professor Wang Jie (an instructor at the school) has formulated a set of critiques, estimating that the academic world must seriously reflect upon and criticise such completely erroneous positions. Professor Wang also suggested that given the current fever for national studies, it is necessary to remain vigilant towards all tendencies to return to the past (fuguzhuyi 復古主義) and towards radical nationalism (jiduan minzuzhuyi 極端民族主義). ${ }^{(74)}$

This article appears in fact in a semi-official discussion space where the subject of Confucianism is broached directly and sometimes defended. The following passages appeared in an article published at the end of 2006 on the site studytimes and written by a high-ranking military official, Xu Zhizin, a general based in Xinjiang, with the title "Leaders and cadres must also study a little classical culture:"

\section{Confucian culture is a cultural resource which we cannot distance ourselves from in the construction of a harmonious socialist society (...) As cadres and leaders, we must nourish ourselves with Confucian culture (...) Every Communist Party cadre must contribute to the radiance of the spiritual specifici- ties of Confucian culture by aspiring to the highest moral qualities and behaviour (...). ${ }^{(75)}$}

Reacting to this article, the Professor Wang mentioned above estimates that it reflects the opinion of many students (who are also cadres) at the CPS. ${ }^{(76)}$ While his position is rather orthodox, as exhibited in the strong criticism of the idea of any institutional role for Confucianism, he nevertheless defines a double mission for the CPS: promoting both Marxism and Chinese traditional culture. Moreover, he launches into an interesting criticism of the institution that, in his opinion, reacted too slowly (with a lag time of ten to twenty years) "to the problem of traditional culture that has absorbed the attention of the whole of society." (77)

72. The actual extent of this phenomenon remains difficult to evaluate but evidence suggests that it is significant.

73. For example zhonggong zhongyang dangxiao, the site of the Central Party School: www.ccps.gov.cn or xuexi shibao, www.studytimes.com.cn. Given the quantity of information, we looked at several websites using the following keywords: guoxue, ruxue, rujia, rujiao, chuantong wenhua etc.

74. http://www.ccsp.gov.cn/xinwen.jsp?daohang name $=\% \mathrm{BD} \% \mathrm{FC} \%$, Zhongyang dangxiao yanjiusheng zhexue luntan shou jiang guoxue, consulted on13 February 2007.

75. Xu Zhuxin, Lingdao ganbu ye yao xue yidian chuantong wenhua, http://www.china.com.cn/xxsb/txt/2006-06/20/content 6249063.html, consulted on 13 February 2007 on the xuexi shibao website.

76. Wang Jie, "Dongxiao yao zhongshi dui youxiu chuantong wenhua de xuanchuan he hongyang shibao," http://www.china.com.cn/xxsb/txt/2006-10/24/cotent 7271511 html, consulted on 13 February 2007 on the xuexi shibao website.

77. Wang Jie, Dangxiao yao zhongshi dui youxiu chuantong wenhua de xuanchuan he hongyang, op. cit. 


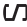

In addition to websites, semi-official literature provides other resources with which to gain an idea of the interest on the part of authorities for Confucianism. ${ }^{(78)}$ Using such literature and the kind of examples cited above, ${ }^{(79)}$ we can emphasize two elements: on the one hand, it appears as though the role of "Confucianism" in the more formal sense of the term can be discussed directly and, as a consequence, that an internal debate is occurring, if only informally among PCC cadres; on the other hand, the positions that appear to be emerging in these circles oscillate between extreme prudence and critical re-appropriation, as if, in the same vein of appraisals of Mao (70\% positive, 30\% negative), the time might have come to re-evaluate the old Master and his influence.

\section{A Political Use of Confucianism Today? The Issue in Intellectual Circles}

For the past few years, within official discourse there has been a multiplication of slogans with Confucian overtones without explicit or in any case exclusive reference to Confucianism or traditional culture. In fact, the desire to blend these slogans with the socialist and Marxist legacy has been evident, which is not too surprising given that the very legitimacy of the regime stems from that heritage. It is particularly in the domains of culture, morality, education or other means of solidifying national cohesion that the role of Chinese "tradition" has been affirmed, without the actual content of this category being precise. However, does this "tradition" offer something additional to the practice of power, to the defining of public policy, or, indeed, to the institutional evolution of the regime? A debate on these kinds of questions is currently taking place within intellectual circles in China. In and of itself, this phenomenon is extremely interesting. Our goal here is simply to point out its existence since it constitutes a part of the general context within which the official discourse we have been analysing emerges. We have already looked at the interaction between authorities and society at large. Intellectuals form collectively the third angle of a triangle, even if it is difficult to discern the actual influence-probably still very modest-that their debates on this subject have on the top leadership. ${ }^{\left({ }^{(0)}\right.}$

The existence within intellectual circles of discussion about Confucianism is, of course, not a new phenomenon. However, the way of viewing Confucianism has evolved considerably in the last thirty years. While in the 1980s, the country's problems were still often blamed on the subsistence of "feudalism," today Confucianism is often seen in a favourable light. An examination of intellectual itinerary of some scholars illustrates this phenomenon. One example is Gan Yang 甘陽, a talented and influential thinker who is considered to be one of the main representatives of the "new left." His view of Confucianism, once consistent with the dominant perspective of the 1980s described above, has evolved. In a recent article, he goes so far as to advocate a "Chinese way" which could take the form of a "Confucian socialist republic" (rujia shehuizhuyi gongheguo 儒家社會主義共和國). ${ }^{(81)}$ In his opinion, the political in China must take into account a triple heritage in which each composing element is important: (a) the first part of the heritage corresponds in some way to the policy of liberalisation launched thirty years ago and oriented towards market forces, "which also includes several concepts that have become familiar, like freedom and rights." (b) The second element is the Maoist heritage which for Gan is important not to forget-"it is a tradition that embodies equality and justice" that is reasserted in the current slogan "harmonious society." (c) Finally, the "Confucian tradition" must be assimilated. By "Confucian tradition" he means most of all a collection of practices inherited from the past that structure "daily life," notably family

78. Numerous semi-official theoretical works, written by teams of researchers working for major state organs, have recently been published. One book worth citing has been written by a team of the Academy of Social Sciences in Shanghai: Wang Ronghua and Tong Shijun (ed.), Duoxueke shiye whong de hexie shehui (The Harmonious Society from a Pluridisciplinary Perspective), Shanghai, Xuelin chubanshe, 2006. In this work it is affirmed that a new inventory of Confucianism needs to be taken. Certain aspects judged positive-ideals (great unity Datong 大同) and values-are deemed usefu while others are designated as meriting rejection (particularly the conception of interpersonal relations illustrated by the san gang 三網) (pp. 326-329, 402). Certain other works travel down the path of positive evaluation far less. See for example Leng Rong and Xia Chuntao (ed.) Kexue fazhan guan yu goujian shehuizhuyi hexie shehui (The Concept of Scientific Development and the Construction of a Harmonious Socialist Society), Beijing; Shehui kexue wenxuan chubanshe, 2007. This book, published by the Centre for Studies of Deng Xiaoping Theory and "Three Represents" Thought of the Chinese Academy of Social Sciences, upholds the standard line of the Marxist vulgate, while dwelling on the question of xiuyang (self-cultivation, p. 208ff), (socialist) morality and the "theory of honours and shames" (rongruguan 榮辱觀) (examined in terms of its relation to scientific development, pp. 225ff)

79. These examples were chosen because they are fairly representative of what can be found on official websites.

80. Chen Ming, one of the representatives of the so-called "Dalu xinrujia" (continental neoconfucianism) and an advocate of cultural conservatism explains that one might have the feeling that there is some sort of tacit understanding between Confucian intellectuals and the authorities. Nevertheless, direct relations between the two are in fact nonexistent. "Chen Ming, Gan Chunsong duihua lu, Zhujian qieru shenghuo de ruxue," (Dialogue between Chen Ming and Gan Chunsong, A Confucianism Gradually Entering Daily Life), in Nandu zhoukan (forthcoming).

81. Gan Yang, "Zhongguo daolu, sanshi nian yu liushi nian," http://www.wyzxwyzx.com/ Article/Class17/200704/17083.html, consulted on 10 April 2007. The article alsoappeared in Dushu, 2007/6 (June), pp.3-13. 
relations. ${ }^{\left({ }^{(2)}\right)}$ Naturally, Gan Yang does not embrace Confucianism uncritically (to the contrary, we can see that he relies on a very reduced meaning of the term), but what is interesting to point out is his intellectual evolution as well as the fact that Confucianism has become for him a concept that is sufficiently promising as to merit being promoted. During the 1990s the position of a considerable number of former liberals of the 1980s shifted towards the new left or towards forms of conservatism. The current decade has seen many of the same intellectuals engage in a critical re-appropriation of aspects of tradition. ${ }^{(83)}$

The debate concerning Confucianism has been nurtured by a group of intellectuals who have more openly claimed a strong institutional role for it. They have distinguished themselves from a Confucianism still embodied during the 1990s by the writings of thinkers in Taiwan, Hong Kong, and the United States. Among these "activist intellectuals" figures Jiang Qing 蔣慶, the author of a book in 2003 titled Political Confucianism (Zhengzhi ruxue 政治儒學) as well as other works. For Jiang, the legitimacy of political authority stems from three sources: heaven (tian 天), which is the incarnation of a certain transcendence; earth ( $d i$ 地), which represents culture and history; and finally man, (ren 人), which reflects notion of the will of the people. This conception of things leads, in his case, to concrete proposals for institutional reform, notably, the establishment of a tri-cameral parliament reflecting the three sources. ${ }^{(84)}$ Jiang Qing is the leader of a group of intellectuals in various disciplines, including the "Confucian economist," Shen Hong 盛洪. Another well-known member of this group of Confucians is Kang Xiaoguang 康曉光, a sociologist and former adviser to Zhu Rongii. Like Jiang, Kang advocates that Confucianism should become an official religion. ${ }^{(85)}$ Such proposals have sparked considerable debate and polemics outside strictly academic circles. Proof of this development is the amount of discussion of the "Confucianisation of China" within the semi-official discourse analysed above. Given the overall context, the Confucian positions put forth by the authors mentioned above cannot fail to generate strong reactions, especially among liberal authors. Thus, for example, Qin Hui 秦睴, a writer whose political preferences lean toward social democracy, has denounced in both books and conferences political practices that have historically claimed Confucian inspiration, arguing that in reality they have reflected a fundamentally legalist spirit ( $r u$ biao fa li 儒表法裹 which means "Confucian on the outside, legalist on the inside). ${ }^{(86)}$ Paradoxically, even the most pointed criticism contributes to Confucianism's presence in intellectual debate at the moment. ${ }^{(87)}$
82. This text by Gan Yang has provoked both considerable debate and severe criticism. See Yi Quan, "Xin gaige gongshi bu neng zou rujia shehuizhuyi daolu (The New Reform Consensus Can Not Lead to Confucian Socialism), in Gaige neican (Bulletin of Internal Information), $\mathrm{n}^{\circ}$. 2006/16, pp. 43-45. See as well Yang Jisheng, "Xiandai minzhu zhidu : yi ge bu neng bei paichu de gaige gongshi (The Contemporary Democratic System: A Consensus on Reform which Cannot Be Put Aside), op. cit., p. 45. The two authors denounce Gan Yang's idealised vision of Maoism and his notion that the Cultural Revolution was an example of "creative destruction" (chuangzaoxing pohua 創造性破壤). Yi Quan asserts that Confucianism has nothing to do with socialism and likens Gan Yang's proposals to Chang Kai-shek's New Life Movement (Xin shenghuo yundong 新生活運動), an effort to unite Confucian values with the Three Principles of the People. Yang Jisheng argues that the kind of social relations promoted by Confucianism is incompatible with the very idea of a republic.

83. In a recent dialogue, two specialists of Confucianism, Gan Chunsong and Chen Ming express very similar views. Indeed, they depict an important switch in the discourses of both the Chinese liberals and the New Left. They notice that the New Left increasingly refers to "Chinese tradition" in its thinking about modernity. "Chen Ming, Gan Chunsong duihua lu, Zhujian qie ru shenghuo de ruxue," op. cit.

84. According to Jiang Qing, the tongruyuan 通儒院 representatives, those embodying Confucian wisdom, would be recruited by examination or by recommendation, whereas the guojiyuan 國體院 representatives (history and culture) would be, for example, descendants of Confucius. Finally, the shuminyuan 庶民院 representatives, representing the people, would be elected as in a Western-style democracy. Jiang Qing, Shengming xinyang yu wangdao zhengzhi, Taibei, Yangzhengtang wenhua shiye gufen youxian gongsi, 2004. See also Jiang Qing, Zhengzhi ruxue, Dangdai ruxue de zhuanxiang, tezhe yu fazhan (Political Confucianism: Development, Characteristics and Orientations of Contemporary Confucianism), Beijing, San lian shudian, 2003. In this book, which was widely discussed in China, Jiang Qing does not elaborate on his institutional proposals. For a recent analysis of Jiang Qing's work see Daniel A. Bell, "Zhengzhi ruxue de zhengzhi hanyi fansi (Reflections on the Political Ideas of Political Confucianism)," to be published in Dushu.

85. Kang Xiaoguang, Renzheng, Zhongguo zhengzhi fazhan de di san jiao daolu (The Sense of Humanity as a basis for Politics: The Third Way of Chinese Political Development), Singapore, Global Publishing, 2005. The positions of Jiang Qing and Kang Xiaoguang cannot be completely assimilated with those of the "Confucian camp." The Confucian "liberals" (often inspired by the movement referred to as "contemporary Confucianism") reject them, as well as certain specialists of Confucianism more influenced by Marxism. Thus, the propagation of an institutional Confucianism is vigorously opposed by Fang Keli, who, in the 1980s, was commissioned by the government to conduct the first research on contemporary Confucianism, which he concluded was an anti-Marxist offensive attempting to Confucianise the party or China. See the Bulletin of the International Confucian League dated 30 March 2007 in which there is a letter by Fang Keli. A research group spearheaded by Fang has just written a combative book denouncing cultural conservatives like Kang Xiaoguang, Jiang Qing, Shen Hong and Chen Ming. They openly deride the project to "Confucianise China" (ruhua Zhongguo). Zhang Shibao (ed.) Dalu sinrujia pinglun (Critical Analysis of Contemporary Mainland China), Beijing, Xianzhuang shuju, 2007.

86. Qin Hui, Chuantong shi lun (Ten Essays on Tradition), Shanghai, Fudan daxue chubanshe, 2003, p.167. Qin Hui is not critical of Confucianism as a system of thought but condemns it as a set of political practices. As an illustration of the Confucian influence on liberal thinking in mainland China, we can point to the presence of some of their representatives, like Liu Juning, at the tenth anniversary celebration of the founding of the journal Yuan Dao, hosted by Chen Ming, a leading cultural conservative. (Joël Thoraval provided this information).

87. Three remarks: (a) as emphasised above, Confucianism was an object of study during precedent periods. But, in our opinion, there is a definite shift at work. It has taken on a much greater importance than it previously enjoyed. The amount of controversy it generates is testimony to this new standing: in particular we are thinking of a debate concerning the work of a Confucian specialist, Li Ling, who has been highly critical of rejuvenated Confucianism, or of another very recent debate, which has spilled a lot of ink, on the need for a new renaissance (wenyifuxing 文藝復興 ) or moral reconstruction (daode jianshe 道德建設); (b) Confucianism, throughout Chinese history, has consisted of a variety of elements (philosophy, practices, crystallisation of habits and modes of thought) and has included, if we limit ourselves to intellectual production, a wide range of authors, to the point that it is not at all surprising that it has engendered a multiplicity of contemporary re-appropriations. Some believe that it is perfectly compatible with liberal democracy (notably the thesis of "contemporary neo-Confucians," often inspired by Song and Ming Confucianism); others with an "illiberal" democracy (for example Jiang Qing and Kang Xiaoguang); others stitch it together with American pragmatism (R. Ames), others with communatarianism (Daniel A. Bell); while a yet another tradition—which appropriates some of the arguments of the others-draws a comparison with socialism (Gan Yang is an example but another we could cite is Li Zehou). The comparison made between non-communist socialism and Confucianism could also prove to be very fruitful at a time when, on the one hand, tradi- 
U

Without doubt, the true influence of Confucian intellectuals or those inspired by that tradition on the regime remains very weak, despite the fact that some, like Kang Xiaogang, actively lobby for their cause. Nevertheless, the notion of a Confucian renaissance (ruxue fuxing 儒學復興) has been echoed in both semi-official quarters (including actual debates) and in the mass media (where there is less of an emphasis on politics). The intellectual debates and the emergence of a "popular Confucianism" together add to the framework within which the regime's own discourse operates, a framework the regime both makes possible and tightly controls.

\section{Conclusion: A Breach in Time?}

We can summarise the central arguments of this article in the following manner: (a) the nature of the relationship between the Communist Party and "Chinese tradition" (understood in the largest sense) is complex, since the legitimacy of the regime stems from a rupture with the old order even though certain aspects of that order (notably in terms of epistemology and the moralisation of politics, what is often call the "sinicisation of Marxism) have been somehow perpetuated; (b) In the last thirty years there has been an evident shift in the regime's attitude towards that "tradition;" Confucian-sounding references figure into the regime's overall political orientation, although great care is taken to provide a Marxist justification for the new concepts and to avoid breaking the thread of ideological continuity; In certain domains, such as culture and education, a turning point nevertheless appears to have been reached whereby classical culture and popular traditions once again enjoy a place of honour or are being reinvented and students are encouraged to take an interest in them; the regime seems to have entered a new period of careful and critical reassessment of "traditional culture" in designating elements compatible with the socialist legacy. ${ }^{\left({ }^{8}\right)}$ (c) While this re-evaluation serves clear political purposes (legitimation, fortifying national cohesion), it is not a simple matter of an authoritarian, top-down, cultural instrumentalism; it is a phenomenon that can be linked to a more general evolution of perspectives on classical culture (and Confucianism) at both the level of society as a whole and within more limited intellectual spheres; in this sense, it reflects a style of rule in which the Party no longer seeks to impose its will directly at all levels of society but instead allows for a certain degree of autonomy while tightly controlling the changes unleashed. ${ }^{\left({ }^{89}\right)}$

I would like to conclude this article by considering a larger question that is important in China today: that of the society's relationship to time. In an important work, the historian François Hartog explores a concept that he calls the historicity regime (régime d'historicité), described as "a heuristic tool that aids in better apprehending (...) mostly moments of temporal crisis that occur, here and there, when the connections between the past, the present and the future come to lose their sense of obviousness." ${ }^{(90)}$ A sort of intermediary between the long duration (la longue durée) and the momentary (l'événement), this concept, according to Hartog, allows us to elucidate the tension between the field of experience and the horizon of expectation. ${ }^{(91)}$ The book provides several examples of moments in which a shift to a new historicity regime took place. Thus, using the writings of Chateaubriand or Tocqueville, he demonstrates how at the end of the eighteenth and beginning of the nineteenth centuries, in the wake of the American and French revolutions, a new order of time emerges, "in which lessons are to come from the future. (...) The former historicity regime, in which the past illuminates the future, is definitively nullified." ${ }^{(92)}$ The end of the twentieth century, a bit before and after 1989, marks the arrival of yet another historicity regime that Hartog, through a study of memory and patrimony, characterises via the idea of the dominance of "presentism" (le présentisme). The future no longer illuminates the present; instead it is the present that gets hypertrophied and overwhelms the horizon through information, globalisation, con-

tion has taken on a new attraction, and, on the other, there is a growing interest in European experiments with social democracy, especially in Sweden (see the recent debate around Xie Tao, a CCP veteran whose call for the institution of social democracy in the review Yanhuang Chunqiu generated significant debate and a public counter attack by conservatives). During the republican period there was a faction of socialist Confucians that included Zhang Junmai and his project for a "third way." See Roger B. Jeans, Jr., Democracy and Socialism in Republican China: The Politics of Zhang Junmai (Carsun Chang), 1906-1941, Lanham, Rowman \& Littlefield, 1997; (c) The political world has also engaged in its own diverse appropriation of Confucianism. Confucianism has not solely served as a means to justify authoritarianism. Thus both Kim Dae-jung in South Korea and Lee Teng-hui in Taiwan have judged Confucianism to be compatible with liberal democracy. It is another element to take into account when considering the relationship between politics and culture in China. (I thank Jean-Pierre Cabestan for having drawn my attention to this point). The renewed interest in Confucianism is ripe with tensions.

88. Here we are only interested in the non-directly religious dimensions to classical culture.

89. For a more extensive analysis of this evolution of the regime see the article by Yves Chevrier cited above, "De la revolution à l'Etat par le communisme," op. cit., pp. 92-113.

90. François Hartog, Régimes d'historicité, Présentisme et experiences du temps, Paris, Editions du Seuil, 2003.

91. Ibid., p. 28. A historicity regime, F. Hartog writes, "is simply the expression of a dominant order of time. Weaving together different regimes of temporality, it is, in the end, a way of translating and ordering experiences of time-manners of articulating the past, present and future - and giving them meaning." He goes on to add a few pages later that "contested as soon as it is established, in fact, never fully established (...), a historicity regimen settles into place slowly and lasts a long time." Ibid., p. 118. He specifies that there are periods of overlap between different regimes (p. 119).

92. Ibid., p. 107 
sumption, ephemera, etc. According to Hartog, the present now manufactures the past and the future that it needs on a daily basis. ${ }^{(93)}$

Lacking the perspective of a lengthier stretch of time with which to judge, it would be of course premature to proclaim that China has entered into a new historicity regime. Nevertheless Hartog's work invites us to wonder to what extent China, given the examples analysed above of the changing relationship towards "tradition" and "Confucianism," might be undergoing a "time crisis" leading to a new organisation of the link between past, present and future. While insufficient on their own to provide a definitive answer to such a question, the elements that we have analysed in this article (official discourse concerning traditional culture) as well as those just evoked (Confucianism within society and in the discourse of intellectual circles) do hint at such a conclusion. They suggest, in effect, that China is currently discovering, at a much larger scale than in the 1980s and 1990s, ${ }^{(94)}$ that its classical tradition, notably its Confucian one-whether real, idealised or rein- vented-is maybe becoming once again a source that is capable of informing the present or the future. At the very least it is escaping from its previous "museumification" (95) to expand the field of experience and collective references, whether at the government level (local, central) or at the individual level. In doing so, it may become a meaningful resource, one capable of producing memory and identity. However, it must be stressed that this re-activation of the past, at a variety of levels, is by no means determined by a monopoly of any given tradition. Indeed, it is plural (as typified by the renewal of interest in religion and the new interpretations of classical philosophy and political experience) and fragmentary. ${ }^{(96)}$ This major return of the past, including the recent past, coincides with (the symptoms are already visible) an increasingly acute collective awareness that contemporary China, far from being just "new," is actually the product more than anything else of the telescoping of many traditions.

\section{- Translated by Christopher Storey}

93. Ibid., p. 200. Hartog provides an illuminating example of the transition from the former historicity regime (dominated by the future) and the current one (under the yoke of the present) through urban planning in Paris. In 1971 the Baltard Pavilions at Les Halles were razed. A few years later (and Hartog cites the preservation of the Orsay train station as an analogy) such destruction would have been impossible and Les Halles would have been preserved as part of the heritage of the nineteenth century."

94. For a perspective on the 1980s and 1990s, see the interview of Joël Thoraval in Esprit. "Conscience historique et imaginaire social, le débat intellectuel des décennies 1980 et 1990," in Esprit, February 2004, pp. 171-183. Joël Thoraval shows how the perspective on the imperial heritage evolved during the 1990 s.

95. Which is not to say that it leaves the museum...0n the contrary, it will be interesting to see in the years to come how the return of tradition will translate itself into heritage, commemorations and expositions of all sorts. The notion of the "museumification" of Confucianism has been coined by Levenson. In 1958, in a well-known manifesto, four major intellectuals (Mou Zongsan, Tang Junyi, Zhang Junmai and Xu Fuguan), who were all very isolated at the time, denounced such a vision of a fossilized Chinese culture.

96. Of course, there remain major zones of collective and highly problematic amnesia (the Cultural Revolution, Tiananmen, etc.). One might even go so far as to speak about a form of "engineered amnesia". However, the phenomenon underway is not the return of the past of historians, but the production of a past to elucidate the present and the future. 